\title{
Current challenges and threats of regional development, the ways to overcome them**
}

\author{
Olha Dzhyhora ${ }^{1}$ \\ PhD in Economics, Associate Professor of Economic Security, Public Administration and Administration \\ Zhytomyr Polytechnic State University
}

JEL Classification: O18, R11, R15, R50

\begin{abstract}
The article is devoted to the study of challenges, the main threats to the development of regions and key ways to overcome them. The strengths and weaknesses, opportunities and threats of the regions have been studied with the help of SWOT-analysis. The interrelations of the regional development SWOT-matrix elements and variants of correlations among internal factors and external influences on the regions development have been determined. The use of graphtheoretic model for quantitative assessment of SWOT-matrix elements (strengths, weaknesses, opportunities, threats) has been proposed, as a result of which the priority opportunities have been identified, which implementation contributes to regional development: deepening integration with the EU, improving the business climate in Ukraine, stimulating the development of small and medium business.
\end{abstract}

Keywords: regional development; SWOT-analysis; theoretical-graph model; strengths; weaknesses; opportunities; threats.

\section{Introduction}

At the present stage of Ukraine development, differences in the level of regions competitiveness are deepening due to global challenges, risks and threats increasing that affect the country and its regions economy, in particular, the development of new generation technologies, social problems, etc. Therefore, there is a need for regional development socio-economic analysis, the comparative advantages, challenges and risks comprehensive analysis, considering their specifics to determine the needs of territories and ways to solve the problems.

\section{Literature review}

Numerous works of domestic scientists are devoted to the study of theoretical approaches to regional development, namely: V.Heetsya, Z.Herasymchuk, T.Zayats, I.Babets, D.Burkaltseva, N.Vavdiyuk, A.Humeniuk, M.Kyzyma, T.Klebanova, S.Stetsenko, A.Sukhorukova, V.Tkach, Y.Kharazishvili, V.Shlemko and others. However, their attention, in the vast majority, is focused on the theoretical aspects of regions sustainable development and the country socio-economic processes regulation.

Corresponding author:

${ }^{1}$ E-mail addresses: olia.bondarevska@gmail.com

ORCID ID: 0000-0001-8490-3917

(c) 2020 O.Dzhyhora

doi: https://doi.org/10.26642/ppa-2020-2(2)-13-23 


\section{The identification of previously unresolved issues and the formulation of research hypotheses}

In order to identify strengths and weaknesses, opportunities and threats to regions socio-economic development, regional development strategies of Zhytomyr, Ivano-Frankivsk, Mykolaiv, Poltava, Sumy regions, which are close to the main criteria (total area, population, gross regional product, the industrial and agricultural potential level, the export-import operations volume, the amount of annual income per 1 person). It enables to consider the heterogeneity of regions socio-economic development in the regional comparisons implementation. The economic system development SWOT analysis has been carried out in order to identify strengths and weaknesses, opportunities and threats (table 1).

Table 1

SWOT-analysis of the analyzed regions economic system

\begin{tabular}{|c|c|}
\hline Strengths & Weakness \\
\hline Favorable geographical location; & Depreciation of existing infrastructure, especially in \\
\hline Significant transit potential, developed network of & housing and communal services and roads; \\
\hline transport infrastructure; & 2. High level of physical depreciation of fixed assets \\
\hline The presence of a large number of productive & in the real sector of the economy; \\
\hline agricultural lands; & High level of energy and resource intensity of \\
\hline Favorable natural and climatic conditions for & production, high dependence on gas; \\
\hline agriculture; & Industry technological backwardness; \\
\hline 5. Diversified agriculture; & Low innovative activity of enterprises, weak links \\
\hline Availability of raw materials for further processing & with research institutions; \\
\hline of agricultural products; & 6. Insufficient diversification of industry and markets; \\
\hline $\begin{array}{l}7 . \quad \text { Highly developed food industry with well-known } \\
\text { brands; }\end{array}$ & $\begin{array}{l}\text { 7. Excessive export orientation to the markets of the } \\
\text { Customs Union countries, including Russia; }\end{array}$ \\
\hline $\begin{array}{l}\text { 8. Availability of significant mineral deposits, } \\
\text { renewable and alternative energy sources, forest } \\
\text { resources; }\end{array}$ & $\begin{array}{l}\text { 8. Lack of regulation and control over the introduction } \\
\text { of chemicals into soils and crop rotations, which leads to } \\
\text { land degradation; }\end{array}$ \\
\hline $\begin{array}{l}\text { 9. Developed industrial potential (engineering, } \\
\text { chemical, oil and gas, mining, food, woodworking, }\end{array}$ & $\begin{array}{l}\text { 9. Non-compliance of certain types of agricultural } \\
\text { products with EU standards; }\end{array}$ \\
\hline production of building materials); & 10. Unsatisfactory condition of roads, especially in rural \\
\hline $\begin{array}{l}\text { 10. Low level of ecological load; } \\
\text { 11. Powerful natural and recreational potential, high } \\
\text { reserves of quality groundwater, including mineral; }\end{array}$ & $\begin{array}{l}\text { areas; } \\
11 . \quad \text { Interregional disparities in socio-economic } \\
\text { development; }\end{array}$ \\
\hline $\begin{array}{l}\text { 12. Significant historical and cultural potential } \\
\text { (presence of objects of architectural, historical and } \\
\text { cultural heritage, presence of local cultural and artistic }\end{array}$ & $\begin{array}{l}\text { 12. Low level of use of alternative and renewable } \\
\text { energy sources, introduction of energy efficient } \\
\text { technologies; }\end{array}$ \\
\hline brands); & Absence of enterprises for processing and \\
\hline 13. Developed network of educational institutions an & utilization of industrial and solid household waste; \\
\hline research institutions. High level of education of the & Difficult demographic situation; \\
\hline population; & High unemployment, especially in rural areas and \\
\hline 14. Skilled labor resources & among young people; \\
\hline & $\begin{array}{l}\text { 16. High labor migration of the population, including } \\
\text { outflow of intellectual resources, youth; }\end{array}$ \\
\hline & $\begin{array}{l}\text { 17. Non-compliance of workers' qualifications with } \\
\text { market requirements }\end{array}$ \\
\hline
\end{tabular}

\begin{tabular}{|c|c|}
\hline Opportunities & Threats \\
\hline $\begin{array}{l}\text { 1. Deepening integration with the EU (emergence of } \\
\text { new markets, export growth); }\end{array}$ & $\begin{array}{l}\text { 1. Political instability, continuation of the anti-terrorist } \\
\text { operation in eastern Ukraine; }\end{array}$ \\
\hline 2. Carrying out administrative reform, & 2. Deepening economic crisis in Ukraine; \\
\hline $\begin{array}{l}\text { decentralization of power, increasing the financial } \\
\text { independence of communities; }\end{array}$ & $\begin{array}{l}\text { 3. Slow implementation of administrative reform, } \\
\text { decentralization of power; }\end{array}$ \\
\hline $\begin{array}{l}\text { 3. Growing demand for food on the world market, } \\
\text { including for fresh organic products; }\end{array}$ & $\begin{array}{l}\text { 4. Weakening of foreign economic relations with the } \\
\text { countries of the Customs Union, reduction of investments; }\end{array}$ \\
\hline $\begin{array}{l}\text { 4. Popularization of ecological way of life, ecological } \\
\text { products consumption, development of organic } \\
\text { agriculture; }\end{array}$ & $\begin{array}{l}\text { 5. Deterioration of competitiveness of Ukrainian } \\
\text { goods due to growing volumes of imported goods from EU } \\
\text { countries; }\end{array}$ \\
\hline $\begin{array}{l}\text { 5. Improving the business climate in Ukraine, } \\
\text { stimulating the development of small and medium-sized }\end{array}$ & $\begin{array}{l}6 . \quad \text { Monopoly of energy supply structures, rising energy } \\
\text { prices; }\end{array}$ \\
\hline businesses; & ndence on imported natural gas \\
\hline $\begin{array}{l}\text { 6. Creating a favorable investment climate, including } \\
\text { by attracting foreign foreign investment; }\end{array}$ & National currency instability, inflation continuation; \\
\hline
\end{tabular}


End of the table 1

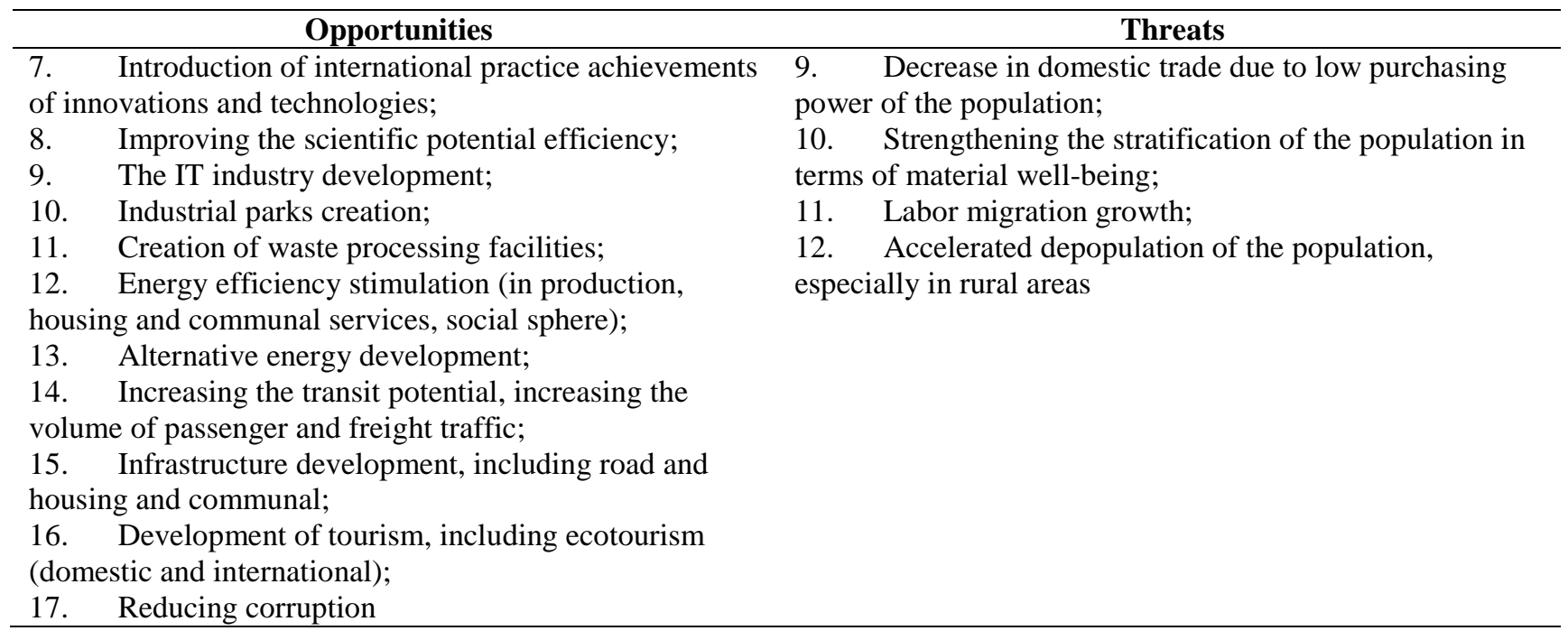

Based on it, to determine the competitive advantages, challenges, security and risks of regions, it is proposed to use SWOTanalysis tools which enables to build a SWOT-matrix and determine the content of links between their elements.

\section{Research methodology and methods}

The purpose of this publication is to identify the regions priority opportunities which implementation contributes to the regional system development. The implementation of opportunities provides support and helps to solve the problems associated with the presence of weaknesses: strengths can eliminate the threats that affect the system weaknesses (fig. 1).

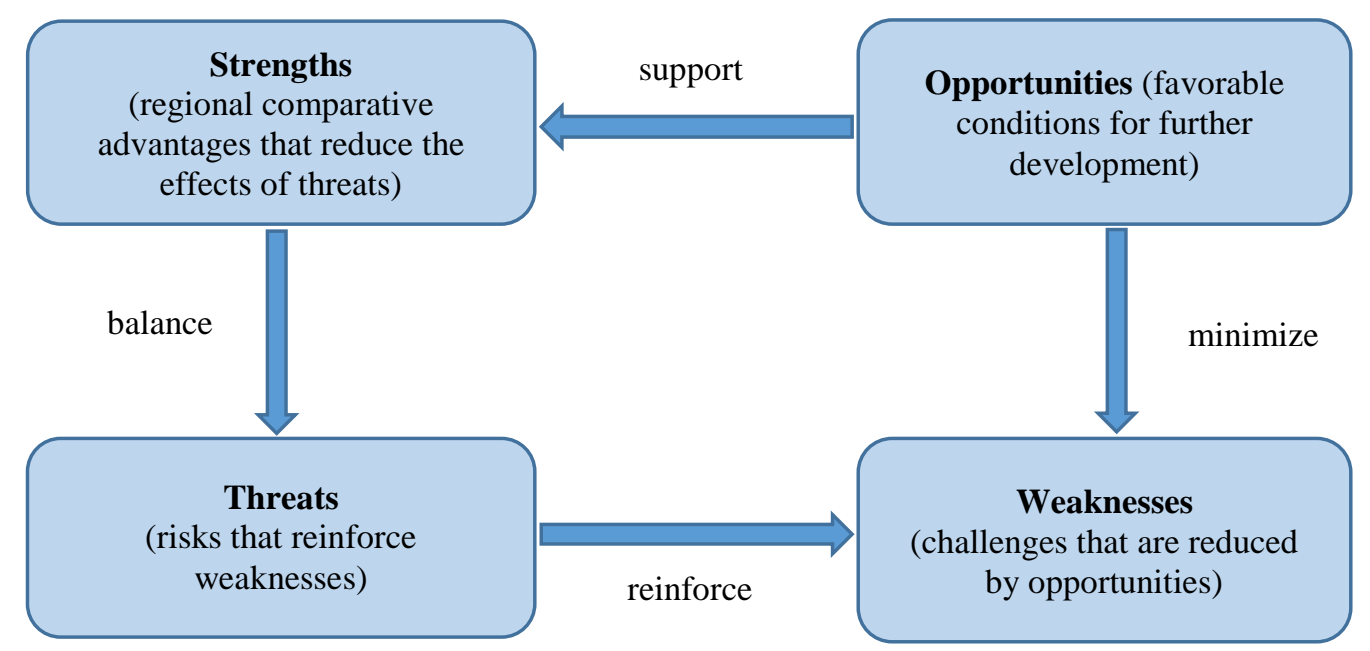

Fig. 1. Relationships of the regional development SWOT-matrix elements

Variants of correlations between internal factors and external influences enable to define further strategy of actions for realization of opportunities in use of strong parties and reduction of influence risks on weak sides. In order to implement the next stage of modeling the interaction among the elements of the SWOT-matrix, quantifying the impact of some of its elements on others and identifying priority opportunities, which implementation contributes to the regional system development, it is proposed to use a graph model. It is constructed a graph $\mathrm{G}$, the vertices of which correspond to the elements of the SWOT-matrix. The set of vertices of this graph has the form

$$
G^{0}=\left\{\alpha_{i}\right\}_{i=1}^{17} \cup\left\{\beta_{j}\right\}_{j=1}^{14} \cup\left\{\gamma_{k}\right\}_{k=1}^{12} \cup\left\{\delta_{l}\right\}_{l=1}^{17}
$$

where $\alpha_{\mathrm{i}}$ - vertices corresponding to the possibilities; $\beta_{\mathrm{j}}$ - vertices that correspond to the strengths; $\gamma_{\mathrm{k}}$ - vertices corresponding to threats; $\delta_{1}-$ vertices that correspond to the weaknesses.

The approximate edges of the graph $\mathrm{G}$ correspond to the connections between the elements of the SWOT-matrix. These ribs are divided into several types. Ribs $\left(\alpha_{\mathrm{i}} \beta_{\mathrm{j}}\right)$ correspond to the relationship between opportunities and strengths and determine which strengths have the most support through the realization of opportunities. Each edge $\left(\alpha_{\mathrm{i}} \beta_{\mathrm{j}}\right)$ corresponds to its weight $\mathrm{f}$ $\left(\alpha_{\mathrm{i}} \beta_{\mathrm{j}}\right)$, which determines the strength of the corresponding bond. Weight values belong to the set $\{1 ; 0,75 ; 0,5 ; 0,25\}$. The presence of such edges and their weight is determined by the matrix $M(\alpha, \beta)$, the elements of which are $f\left(\alpha_{\mathrm{i}} \beta_{\mathrm{j}}\right)$. The subgraph $G \alpha \beta$ of the graph $G$ on the set of vertices corresponding to the capabilities and strengths is shown in figure 2 . 


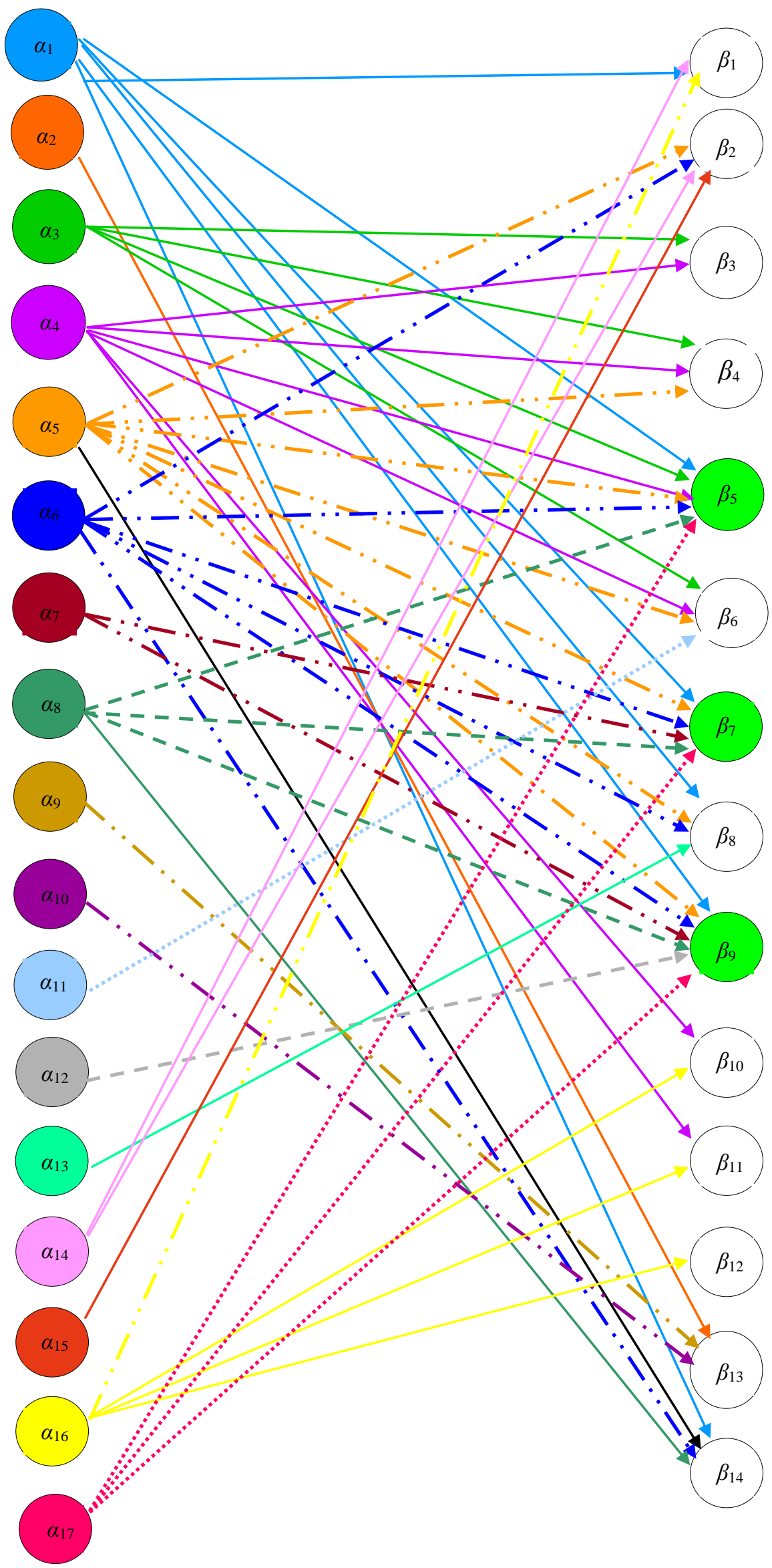

Fig. 2. Subgraph $G \alpha \beta$, which reflects the impact of opportunities on strengths 


\section{Main results}

Given the limited financial resources, it is necessary to prioritize the allocation of resources and focus on those strengths that can provide the highest results in the shortest possible time and have a long-term and comprehensive impact on the development of not only this area but also neighboring regions.

Due to constructing a subgraph of $G \alpha \beta$ links between strengths and opportunities, it is established that to increase the level of economic development of selected regions, the greatest support through the implementation of favorable opportunities should be given to the following strengths: development of diversified agriculture, developed industrial potential, highly developed food industry brands. It is facilitated by the following opportunities: Ukraine integration into the European space, growing demand for food on the world market, including for organic products; improving the business climate in Ukraine and stimulating the development of small and medium-sized businesses, creating a favorable investment climate, including by attracting foreign investment; increasing the scientific potential efficiency; reducing corruption.

The edges $\left(\beta_{\mathrm{j}} \gamma_{\mathrm{k}}\right)$ correspond to the links between strengths and threats and identify strengths that mitigate threats. Each edge $\left(\beta_{\mathrm{j}} \gamma_{\mathrm{k}}\right)$ corresponds to its weight $f\left(\beta_{\mathrm{j}} \gamma_{\mathrm{k}}\right)$, which determines the strength of the corresponding bond. Weight values belong to the set $\{1 ; 0,75 ; 0,5 ; 0,25\}$. The presence of such edges and their weight is determined by the matrix $M(\beta, \gamma)$, the elements of which are $f\left(\beta_{\mathrm{j}} \gamma_{\mathrm{k}}\right)$. The subgraph $G \beta \gamma$ of the graph $G$ on the set of vertices corresponding to the strengths and threats is shown in figure 3.

As a result of the subgraph $G \beta \gamma$, it has been revealed that strengthening the strengths of the economic system of the analyzed regions neutralize the following threats: deepening economic crisis in Ukraine, weakening foreign economic relations with the Customs Union, reducing investment, deteriorating competitiveness of Ukrainian goods due to growing imports, instability of the national currency exchange rate, preservation of inflationary influences, strengthening of the population stratification by the level of material well-being. Among the main strengths that compensate for the effects of threats are: the diversified agriculture development, developed industrial potential, the availability of raw materials for further processing of agricultural products, highly developed food industry with well-known brands, the presence of significant mineral deposits, renewable and alternative energy resources.

Ribs $\left(\gamma_{\mathrm{k}} \delta_{\mathrm{l}}\right)$ correspond to the links between threats and weaknesses and identify the weakest points (internal factors) of the subject of analysis under the influence of negative external factors - threats, i.e. the most likely risks in the further implementation of regional development plans which should be avoided or whose impact should be minimized through the choice of strategic decisions). Each edge $\left(\gamma_{\mathrm{k}} \delta_{\mathrm{l}}\right)$ corresponds to its weight $f\left(\gamma_{\mathrm{k}} \delta_{1}\right)$, which determines the corresponding bond strength. Weight values belong to the set $\{1 ; 0,75 ; 0,5 ; 0,25\}$. The presence of such edges and their weight are determined by the matrix $M(\gamma, \delta)$, the elements of which are $f\left(\gamma_{\mathrm{k}} \delta_{\mathrm{l}}\right)$. The subgraph $G \gamma \delta$ of the graph $G$ on the set of vertices corresponding to threats and weaknesses is shown in figure 4.

Subgraph $G \gamma \delta$ identified the weakest aspects of the regions`economic system under the influence of negative external factors (with a high probability of their development into threats), including: high labor migration (including outflow of intellectual resources, youth), interregional disparities in socio-economic development, difficult demographic situation, high unemployment, especially in rural areas and among young people.

The main threats to the weaknesses are political instability, the continuation of the Joint Forces Operation in eastern Ukraine, the deepening economic crisis in Ukraine, population accelerated depopulation (especially in rural areas), labor migration growth, and material well-being the intensification.

The edges $\left(\alpha_{\mathrm{i}} \delta_{1}\right)$ correspond to the connections between opportunities and weaknesses and identify weaknesses that can be eliminated through opportunities. Each edge $\left(\alpha_{\mathrm{i}} \delta_{1}\right)$ corresponds to its weight $f\left(\alpha_{\mathrm{i}} \delta_{1}\right)$, which determines the strength of the corresponding bond. Weight values belong to the set $\{1 ; 0,75 ; 0,5 ; 0,25\}$. The presence of such edges and their weight are determined by the matrix $M(\alpha, \delta)$, the elements of which are $f\left(\alpha_{\mathrm{i}} \delta_{1}\right)$. The subgraph $G \alpha \delta$ of the graph $G$ on the set of vertices corresponding to the capabilities and weaknesses is shown in figure 5.

The constructed subgraph $G \alpha \delta$ enables to establish opportunities that have a positive effect on weaknesses. Due to the implementation of opportunities, the following weaknesses can be minimized: technological backwardness of industry, low innovation activity of enterprises and weak links with research institutions, high unemployment (including in rural areas and among young people), inconsistency of certain types of agricultural products EU standards. Opportunities that reduce the vulnerability of the region's economic system are deepening integration with the EU, improving the business climate in Ukraine, stimulating the development of small and medium-sized businesses, creating a favorable investment climate, including by attracting foreign investment, introduction of international practice achievements in innovation and technology, IT industry development, industrial parks creation.

Thus, due to the implementation of opportunities, the following weaknesses of regional development can be minimized: industry technological backwardness, low innovation activity of enterprises and weak links with research institutions, high unemployment (including in rural areas and among young people), non-compliance of certain types of agricultural products with EU standards.

Let us include in the set of edges of the graph $G$ the edges $\left(\alpha_{\mathrm{i}} \gamma_{\mathrm{k}}\right)$ that correspond to the connections between opportunities and threats. The strength of the corresponding connections is determined by the weights $f\left(\alpha_{\mathrm{i}} \gamma_{\mathrm{k}}\right)$, which are calculated on the basis of this graph-based model. Suppose that there exist edges $\left(\alpha_{\mathrm{i}} \beta_{\mathrm{j}}\right)$ in the graph $G\left(\beta_{\mathrm{j}} \gamma_{\mathrm{k}}\right)$. This means that the realization of the possibility that corresponds to the vertex $\alpha_{\mathrm{i}}$ reinforces the strength that corresponds to the vertex $\beta_{\mathrm{j}}$, which in turn helps to overcome the threat that corresponds to the vertex $\gamma_{\mathrm{k}}$. The impact of the $i$-th opportunity to overcome the $k$-th threat based on 
the strengthening of the $j$-th strength is estimated by the value of $f\left(\alpha_{\mathrm{i}} \beta_{\mathrm{j}}\right) f\left(\beta_{\mathrm{j}} \gamma_{\mathrm{k}}\right)$, and the total impact of the corresponding opportunity to overcome this threat is determined by the equality:

$$
f\left(\alpha_{\mathrm{i}} \gamma_{\mathrm{k}}\right)=\sum_{\mathrm{j}=1}^{14} f\left(\alpha_{\mathrm{i}} \beta_{\mathrm{j}}\right) f\left(\beta_{\mathrm{j}} \gamma_{\mathrm{k}}\right) .
$$

It means that there is equality

$$
M(\alpha, \gamma)=M(\alpha, \beta) M(\beta, \gamma),
$$

where $M(\alpha, \gamma)$ - a matrix which elements are $f\left(\alpha_{\mathrm{i}} \gamma_{\mathrm{k}}\right)$.

Let us include in the set of edges of the graph $G$ the edges $\left(\alpha_{\mathrm{i}} \delta_{1}\right)$, which correspond to the connections between opportunities and weaknesses. The strength of the corresponding connections is determined by the weighting factors $f\left(\alpha_{\mathrm{i}} \delta_{1}\right)$, which are calculated on this theoretical-graph model basis. Suppose that there exist edges $\left(\alpha_{\mathrm{i}} \gamma_{\mathrm{k}}\right)$ and $\left(\gamma_{\mathrm{k}} \delta_{\mathrm{l}}\right)$ in the graph $G$. This means that the realization of the possibility corresponding to the vertex $\alpha_{\mathrm{i}}$ helps to overcome the threat that corresponds to the vertex $\gamma_{\mathrm{k}}$, which in turn helps to overcome the threat, which affects the weak side that corresponds to the vertex $\delta_{\mathrm{l}}$. The impact of the $i$-th possibility on the $l$-th weakness based on overcoming the $k$-th threat is estimated by the value of $f\left(\alpha_{\mathrm{i}} \gamma_{\mathrm{k}}\right) f\left(\gamma_{\mathrm{k}} \delta_{\mathrm{l}}\right)$, which is determined by the equality

$$
f\left(\alpha_{\mathrm{i}} \delta_{1}\right)=\sum_{\mathrm{j}=1}^{12} f\left(\alpha_{\mathrm{i}} \gamma_{\mathrm{k}}\right) f\left(\gamma_{\mathrm{k}} \delta_{1}\right)
$$

It means that there is equality

$$
M^{\prime}(\alpha, \delta)=M(\alpha, \gamma) M(\gamma, \delta),
$$

where $M^{\prime}(\alpha, \delta)$ - a matrix which elements are $f\left(\alpha_{\mathrm{i}} \delta_{1}\right)$.

The overall impact of opportunities on weaknesses is reflected by the matrix $M(\alpha, \delta)+M^{\prime}(\alpha, \delta)$. The subgraph $M \alpha, \delta$, which reflects the overall impact of opportunities on the weaknesses, is shown in figure 6 .

\begin{tabular}{|c|c|c|}
\hline \multirow{2}{*}{ Subgraph } & Influence of elements & The result of impact modeling \\
\hline & \multicolumn{2}{|r|}{ Influence of elements } \\
\hline \multirow{3}{*}{$\begin{array}{l}G \alpha \beta \\
\text { (opportunities- } \\
\text { strengths) }\end{array}$} & \multirow{3}{*}{$\begin{array}{c}\text { support for strengths through } \\
\text { the realization of } \\
\text { opportunities }\end{array}$} & diversified agriculture \\
\hline & & developed industrial potential \\
\hline & & highly developed food industry with well-known brands \\
\hline \multirow{7}{*}{$\begin{array}{c}G \beta \gamma \\
\text { (strengths and threats) }\end{array}$} & \multirow{7}{*}{$\begin{array}{l}\text { threats neutralized by the } \\
\text { action of strengths }\end{array}$} & deepening economic crisis in Ukraine \\
\hline & & $\begin{array}{l}\text { weakening foreign economic relations with the countries of } \\
\text { the Customs Union }\end{array}$ \\
\hline & & reduction of investments \\
\hline & & $\begin{array}{l}\text { deterioration of the competitiveness of Ukrainian goods due } \\
\text { to the growth of imported goods from EU countries }\end{array}$ \\
\hline & & instability of the national currency \\
\hline & & continuation of inflationary processes \\
\hline & & $\begin{array}{c}\text { strengthening the stratification of the population in terms of } \\
\text { material well-being }\end{array}$ \\
\hline \multirow{4}{*}{$\begin{array}{c}G \gamma \delta \\
\text { (threats and } \\
\text { weaknesses) }\end{array}$} & \multirow{4}{*}{$\begin{array}{l}\text { weaknesses that are } \\
\text { exacerbated by threats }\end{array}$} & $\begin{array}{l}\text { high labor migration of the population (including the } \\
\text { outflow of intellectual resources, youth }\end{array}$ \\
\hline & & interregional disparities in socio-economic development \\
\hline & & difficult demographic situation \\
\hline & & $\begin{array}{l}\text { high unemployment, especially in rural areas and among } \\
\text { young people }\end{array}$ \\
\hline \multirow{4}{*}{$\begin{array}{l}G \alpha \delta \\
\text { (opportunities and } \\
\text { weaknesses) }\end{array}$} & \multirow{4}{*}{$\begin{array}{l}\text { weaknesses of the regions, } \\
\text { which are minimized } \\
\text { through the realization of } \\
\text { opportunities }\end{array}$} & technological backwardness of industry \\
\hline & & $\begin{array}{c}\text { low innovative activity of enterprises and weak links with } \\
\text { research institutions }\end{array}$ \\
\hline & & $\begin{array}{l}\text { high unemployment (including in rural areas and among } \\
\text { young people) }\end{array}$ \\
\hline & & $\begin{array}{l}\text { non-compliance of certain types of agricultural products } \\
\text { with EU standards }\end{array}$ \\
\hline \multirow{3}{*}{$\begin{array}{l}M \alpha, \delta \\
\text { (opportunities and } \\
\text { weaknesses) }\end{array}$} & \multirow{3}{*}{$\begin{array}{l}\text { opportunities that have the } \\
\text { greatest impact on } \\
\text { overcoming weaknesses }\end{array}$} & deepening integration with the EU \\
\hline & & improving the business climate in Ukraine, \\
\hline & & stimulating the development of small and medium business \\
\hline
\end{tabular}

Modeling general results of the region economic system elements relationships are shown in table 2.

Table 2

The result of modeling the relationships of the region economic system elements 


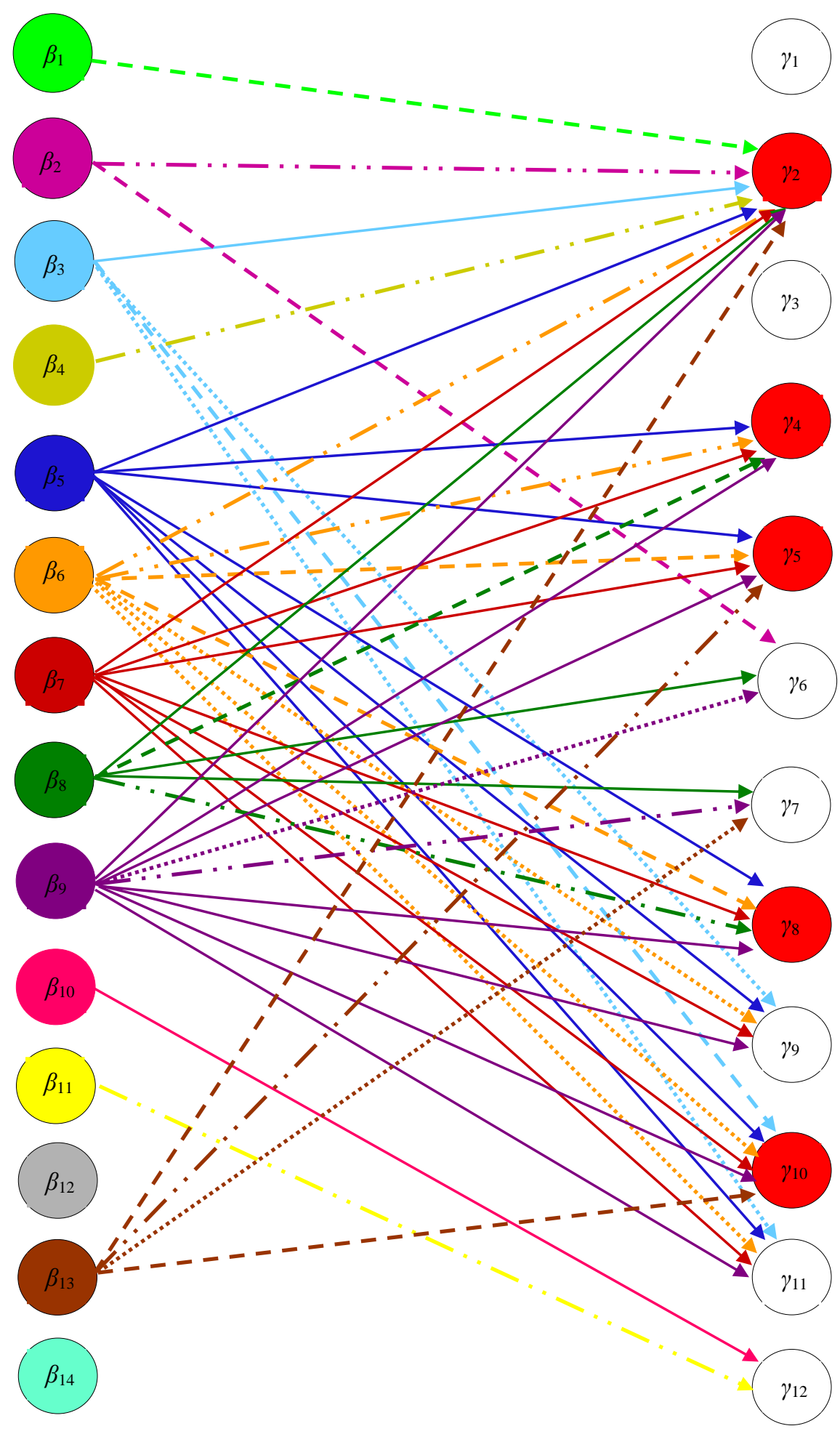

Fig. 3. Subgraph $G \beta \gamma$, which reflects the influence of strengths on threats 


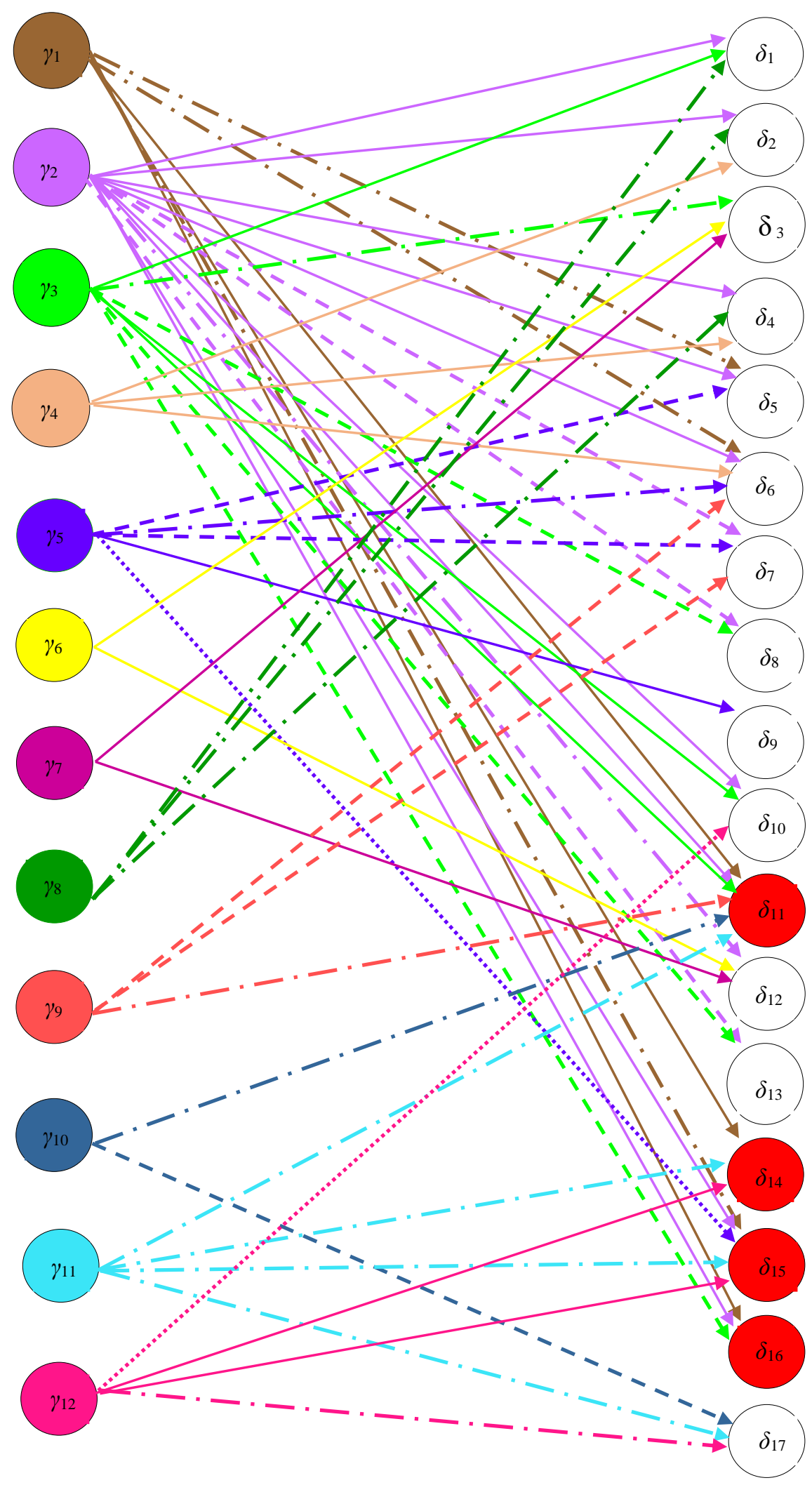

Fig. 4. Subgraph $G \gamma \delta$, which reflects the impact of threats on weaknesses 


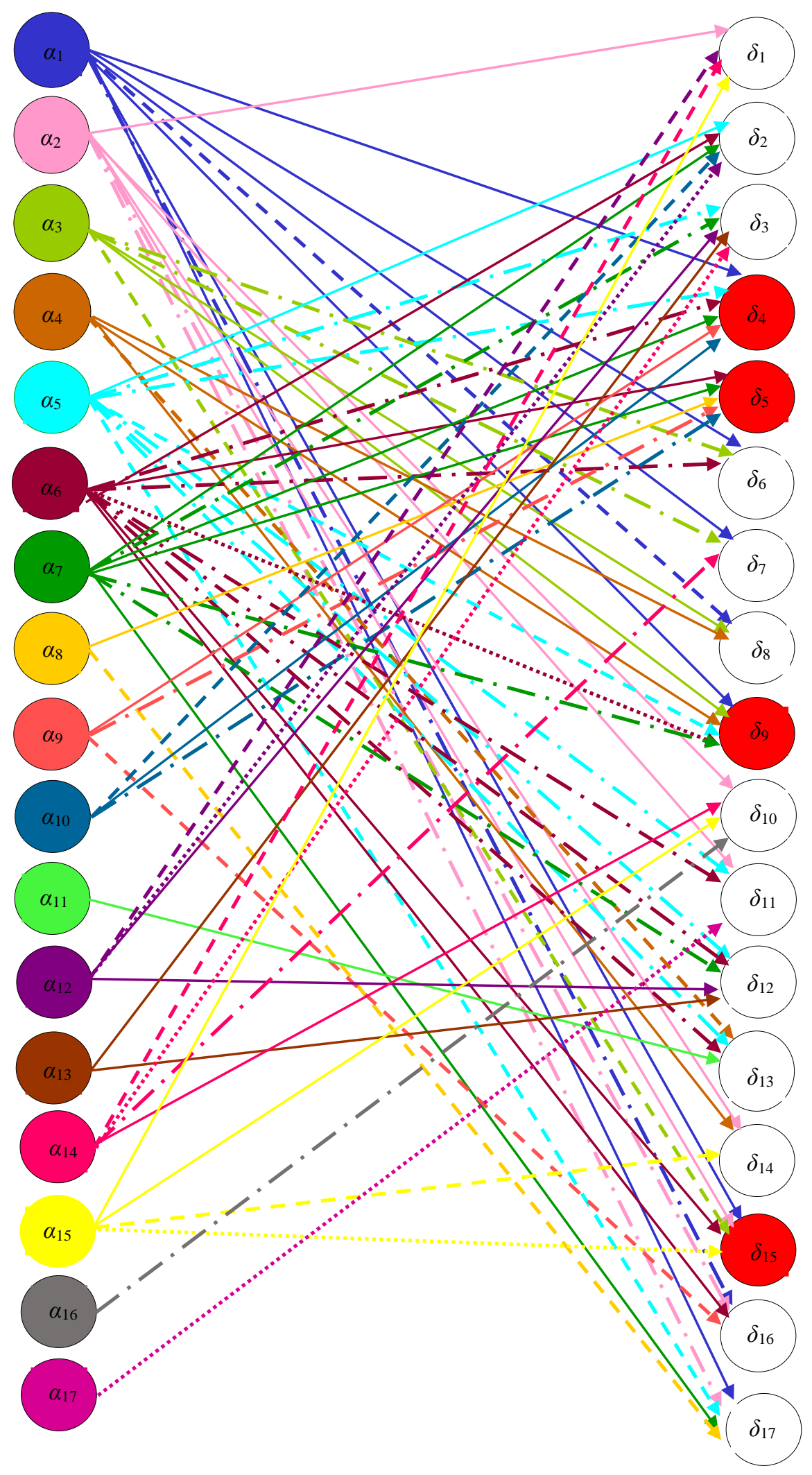

Fig. 5. Subgraph $G \alpha \delta$, which reflects the impact of opportunities on weaknesses 


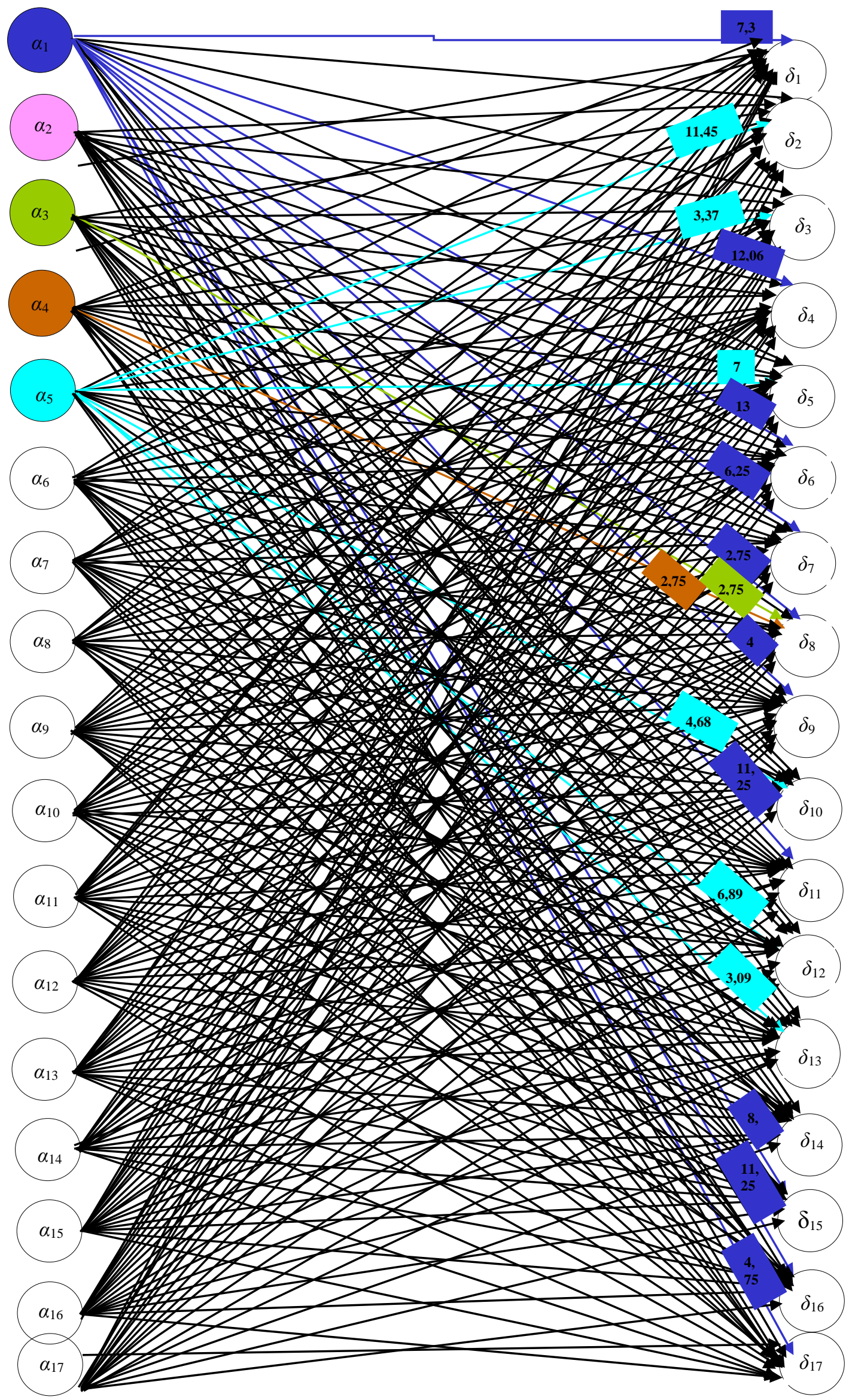

Fig. 6. Subgraph $M \alpha, \delta$, which reflects the impact of opportunities on weaknesses 


\section{Concluding remarks}

Based on the results of modeling and quantitative assessment of the system elements impacts, priority opportunities have been identified, the implementation of which contribute to regional development: deepening integration with the EU, improving the business climate in Ukraine, stimulating small and medium business development.

The advantages of the proposed approach include the fact that it reduces the consequences of subjective assessment of socio-economic development of regions, risks and threats that affect the dynamics of socio-economic processes, determine the level of their economic security in general and the proposed components.

Practical application of the obtained results - the developed methodological approach can be used to substantiate the state priorities of regional development of similar regions (selected on the basis of cluster method and enables to determine the main directions of their development management at the state level): development priorities of specific regions and their development strategies formation or adjustment.

Areas of further research in this area are related to the development of an effective program to ensure the regional development security.

\section{References:}

1. Pro zatverdzhennia Derzhavnoi stratehii rehionalnoho rozvytku na period do 2020 roku, Postanova KMU vid 06.08.2014 No. 385 , [Online], available at: https://zakon.rada.gov.ua/laws/show/385-2014-\%D0\%BF\#Text

2. Stratehiia rozvytku Zhytomyrskoi oblasti na period do 2020 roku, [Online], available at: http://economyzt.gov.ua/files/Strateg/strategia2020.pdf

3. Stratehiia rozvytku Ivano-Frankivskoi oblasti na period do 2020 roku, [Online], available at: http://www.if.gov.ua/page/19310

4. Stratehiia rozvytku Mykolaivskoi oblasti na period do 2020 roku, [Online], available at: https://economy-mk.gov.ua/index.php/ua/

5. Stratehiia rozvytku Poltavskoi oblasti na period do $2020 \mathrm{roku}$, [Online], available at: https://www.adm-pl.gov.ua/page/strategiyarozvitku-poltavskoyi-oblasti-do-2020-roku-0

6. Stratehiia rehionalnoho rozvytku Sumskoi oblasti na period do 2020 roku, [Online], available at: http://sm.gov.ua/ru/oda/6113

7. Zykov, A.A. (1987), Osnovy teorii grafov, Nauka, Moskva, 384 p.

8. Ore, O. (1980), Teoriya grafov, 2nd ed., Nauka: Glavnaya redakciya fiziko-matematicheskoj literatury, Moskva, 315 p.

\footnotetext{
${ }^{* *}$ How to cite this article: Dzhyhora O. Current challenges and threats of regional development, the ways to overcome them. Public Policy and Accounting. 2020, Vol. 2. https://doi.org/10.26642/ppa-2020-2(2)-13-23.
} 